\title{
Role of Government Policies to Fintech Adoption and Financial Inclusion: A Study in Pakistan
}

\author{
Misbah Noreen $^{1}$, M. S. Mia ${ }^{1, *}$, Zahiruddin Ghazali $^{1}$, Ferdoushi Ahmed $^{2}$ \\ ${ }^{1}$ School of Economics, Finance and Banking (SEFB), Universiti Utara Malaysia (UUM), 06010 Sintok, Kedah, Malaysia \\ ${ }^{2}$ Faculty of Economics, Prince of Songkla University (PSU), Hat Yai, Songkhla, 90112, Thailand
}

Received September 11, 2021; Revised November 25, 2021; Accepted December 13, 2021

\begin{abstract}
Cite This Paper in the following Citation Styles
(a): [1] Misbah Noreen, M. S. Mia, Zahiruddin Ghazali, Ferdoushi Ahmed, "Role of Government Policies to Fintech Adoption and Financial Inclusion: A Study in Pakistan," Universal Journal of Accounting and Finance, Vol. 10, No. 1, pp.37-46, 2022. DOI: 10.13189/ujaf.2022.100105.
\end{abstract}

(b): Misbah Noreen, M. S. Mia, Zahiruddin Ghazali, Ferdoushi Ahmed (2022). Role of Government Policies to Fintech Adoption and Financial Inclusion: A Study in Pakistan. Universal Journal of Accounting and Finance, 10(1), 37-46. DOI: 10.13189/ujaf.2022.100105.

Copyright $\mathrm{C} 2022$ by authors, all rights reserved. Authors agree that this article remains permanently open access under the terms of the Creative Commons Attribution License 4.0 International License

\begin{abstract}
Purpose- Pakistan is a lower-middle-income country and financial inclusion rate is comparatively lower than other South Asian countries. In this circumstance, Government of Pakistan has

findings of this study might be useful for the decision makers and practitioners to implement the policies and strategies more effectively and efficiently to enhance the rate of financial inclusion in country.
\end{abstract} implemented various financial inclusion policies and strategies to enhance the rate of financial inclusion in the country. However, a cursory attention has been paid to Government policies by the previous studies. Therefore, the aim of this study is to provide an insight into the current government policies and strategies for fintech adoption and financial inclusion in Pakistan. Design/ methodology/ approach- This study collected and reviewed previous literature that focused on various fintech adoption and financial inclusion policies and strategies by the Government of Pakistan. Literature has been selected from various secondary sources such as journal articles, conference proceedings, annual reports of SBP (State Bank of Pakistan), Global findex report by World Bank and so on. Findings- The study found that Government of Pakistan has successfully implemented a number of financial inclusion policies and strategies during the last decade. A noteworthy innovation approach (i.e. fintech) was applied as a catalyst in order to extend the scope of financial services in Pakistan. The Government also implemented Financial Literacy Programs specifically for youth to create awareness about financial resource management in the country. Very recently, Government of Pakistan launched banking on equality program to enhance gender equality in financial inclusion. Originality/value- The Policies, Pakistan

\section{Introduction}

Financial inclusion is the availability, access, and usage of financial products and services for underprivileged people [1]. Financial inclusion could be in the form of savings, access to the bank account, insurance, and availability of credit facility to underprivileged society at an affordable cost transparently and fairly by formal and informal financial institutions [2]. Prasad [3] defines digital financial inclusion as offering financial services to people by the means of information communication technologies at an affordable cost and in a sustainable manner that suits the customer's need. Digital financial inclusion may also be characterized as access to and usage of formal and informal financial services by means of smartphone.

The purpose of financial inclusion is to provide easy access of the unbanked, disadvantaged and deprived individuals to the formal financial system at an affordable
Keywords Fintech, Financial Inclusion, Government 
cost $[4,5]$. It is demonstrated that financial inclusion leads to reduction in poverty and inequality. Therefore, financial inclusion is essential for financial development and also plays an important role in sustainable economic development [1]. Financial inclusion plays a vital role in sustainable economic growth and could contribute to the potential of saving, flourishing investment, make better consumption, and also provide better living standards $[4,6$, $7,8]$.

The rate of financial inclusion is higher in developed countries, while it is lower in less-developed countries [9]. Makina [10] found that in developed countries, $96 \%$ of adults have financial accounts compared with just $65 \%$ in less-developed countries. Demirguc-Kunt et al. [9] stated in Global findex 2017 that around half of the unbanked adult population was comprised in seven nations, namely: Pakistan, Nigeria, Mexico, Bangladesh, India, China, and Indonesia.

The prevailing low rate of financial inclusion diverges the attention of national and international authorities to launch innovative technologies particularly fintech to provide easy access to financial services and products. Fintech is one of the financial services that are most dynamic, engaging, and energetic. Fintech is the composite of two different words: finance and information technology; that is not a catchphrase [11]. Fintech describes several innovative technologies that are capable of transforming the financial services sector. Fintech offers particular financial products or services innovatively by using the internet and smartphone apps [1]. The emergence of a digital platform provides the facility to the customer to get technology-based financial services and products which were previously offered by the banks.

Thus, the digital revolution is marked by the combination of technologies and cyber-physical structures that blur the lines among finance, economics, and digital spheres [10]. From last few years, term digital finance which encompass the digital payment, mobile wallet, digital financial inclusive has become a relevant and attractive topic among policymakers, Government officials, regulators and customer as well $[12,13]$. A multinational company McKinsey \& Co released a digital financing report that explains the meaning of digital finance [14]. Digital finance means "financial services delivered via digital channels including mobile and internet with rare use of cash and traditional bank branches" [15].

The finance industry in the majority of the countries around the world is utilizing a major part of its revenue on information technology $[5,16]$. The emerging of fintech has great potential to attract several new customers to enhance financial inclusion because of its easy-to-use and low-cost characteristics $[10,13]$. However, the rate of financial inclusion in Pakistan is very poor and is reflected among other South Asian countries as the least financially inclusive country. Figure 2 shows the proportion of adults with an account in South Asian countries.

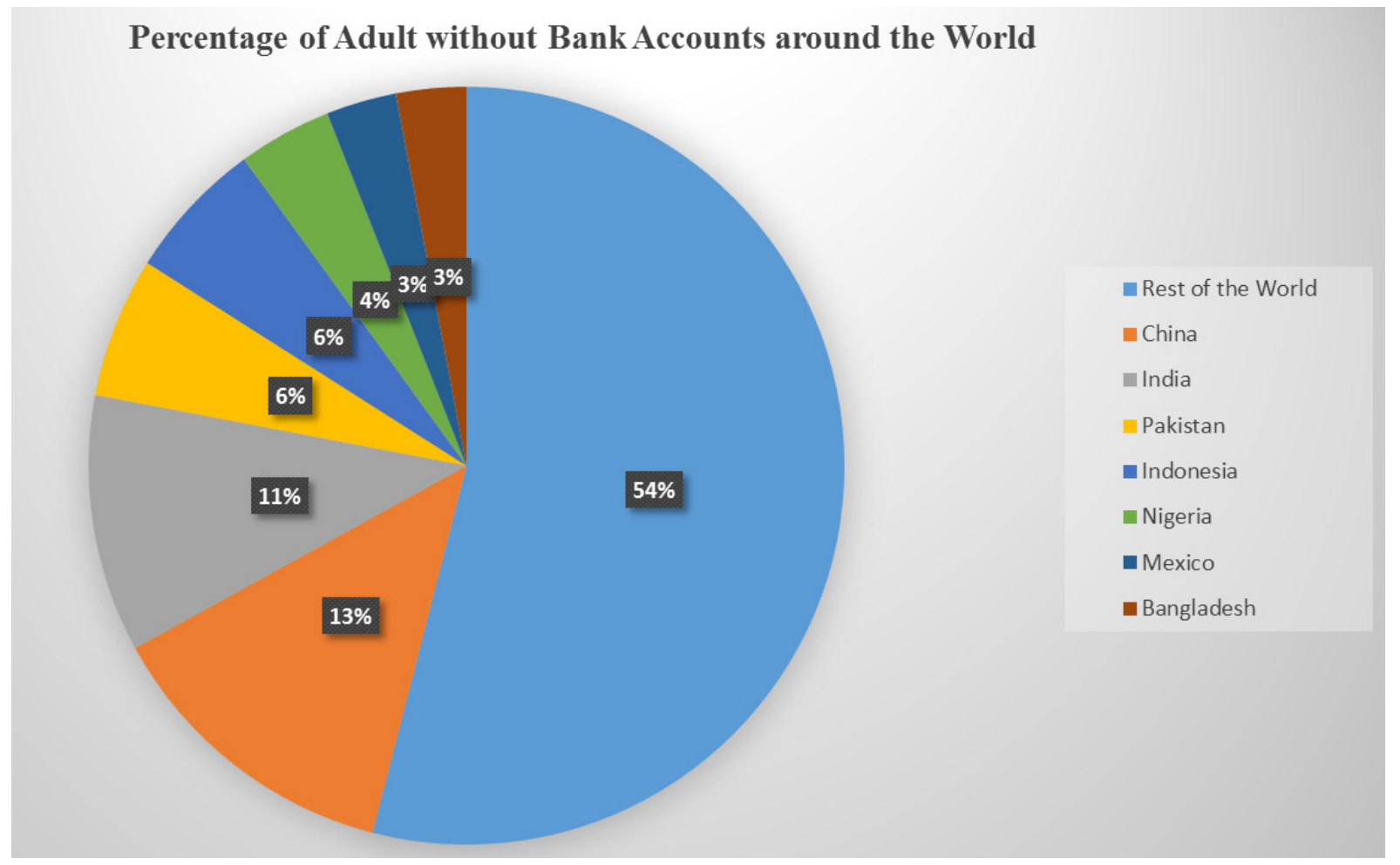




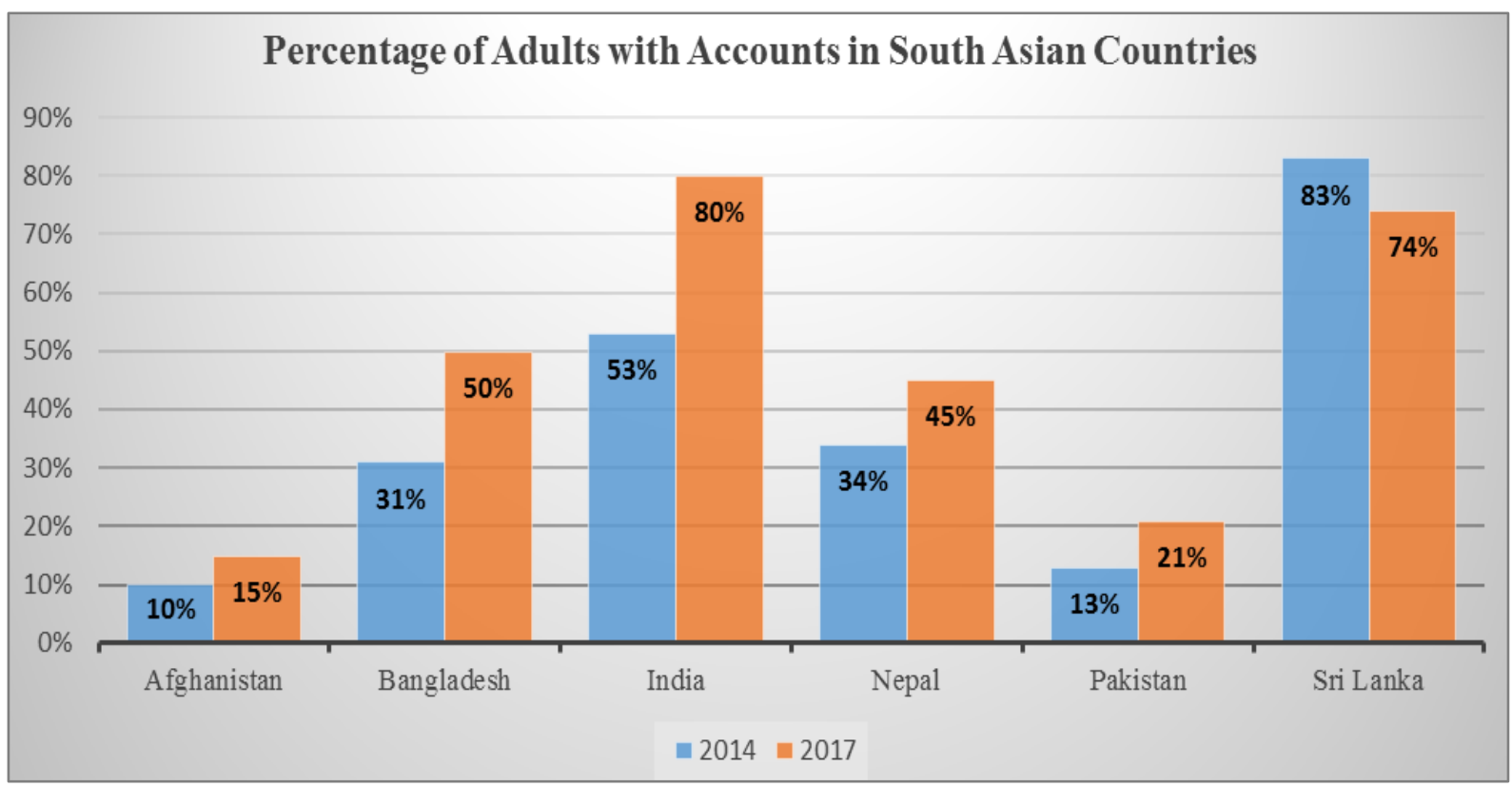

Source: Global Findex 2017

Figure 2. Proportion of Adults with Accounts in South Asian Countries

Pakistan is a lower-middle-income country with, prevailing low rate of literacy and financial inclusion [17]. A major chunk of the population in the country has a lack of access to financial services and is unbanked [6]. The high cost of banks' products and services averts the spread of financial services to the underprivileged society. Lack of access to basic financial services in Pakistan is a dominant issue nowadays [13]. However, technology-based financial services serve as a bridge to overcome problems of far-located and costly services. In these circumstances, the Government of Pakistan has taken steps to launch several policies and strategies to implement fintech services to diverge toward the inclusive financial system. Therefore, the emergence of fintech not only includes digitalization tools but also has great potential to improve financial inclusion. However, no study has been done yet to focus on the various strategies and policies taken by the Government of Pakistan. In other words, less attention has been paid to the financial inclusion policies taken by the SBP to enhance financial inclusion by means of fintech. Therefore, this study aims to review the role of government policies and strategies for fintech adoption and financial inclusion in Pakistan. The study provides an insight into the fintech-related policies and strategies taken by the SBP to enhance financial inclusion in the country during the last decade.

\section{Literature Review}

Financial inclusion is described in sustainable manner as, the provision of valuable and reliable financial services at inexpensive rates for the underprivileged and low-income people [18]. In addition, financial inclusion might be described as insurance products, credit, increased access to financial services, accessibility and usage of bank accounts, modes of payments, investment, and savings [19].

The concept of financial inclusion has not been agreed upon in general until now. However, the UNCDF described the vision of inclusive finance by access to financial services including deposits, credit, pensions, insurance, mortgages at an affordable cost for all households and businesses [20]. In addition to accessing and using banks accounts and formal financial services, another researcher has expanded the reach of financial inclusion, including the quality of services, usage of financial services and impact of financial services as measurements [21, 22]. While quality refers to the application of financial products and service to the user's lifestyle, usage emphasizes the durability and scope of financial service, while impact depicts the changes in socio-economic lives of users [23] Another essential point, "full" financial inclusion means getting access and usage of innovative financial services for every household, comprising deposits, loan, insurance, online payments, having adequate education, moral support and advice, and assist customers to make an appropriate choice for selection of goods [22, 24].

According to World Bank, access and usage of financial services is a critical footstep towards decreasing poverty and inequality in a deprived community [25]. Financial inclusion lets individuals make savings for future claims, borrowing to run a business, and create an emergency cushion. According to [26], that access to financial services is critical for progress as it improves the resource mobilization that is required for fruitful investment and enables households for smooth consumption [27]. 
Fintech can be defined as the usage of mobiles, computers, and digital technology to regulate financial services and it helps to redefine the work of financial entities. Fintech has gradually changed our lives and contributed in the form of mobile money and internet of things. According to Zavolokina, Dolata, and Schwabe [28] "Fintech" denotes the integration of "finance" and "information technology." Fintech is a widespread emerging term that defines several innovative technologies implemented by service institutions [29].

Fintech will contour the future of the service industry. Technological innovations have eliminated the dependence on traditional financial institutions [30, 31, 32]. The introduction of mobile money, branchless banking, and several other financial applications have at present left an impact across the world. Wójcik [33] stated that fintech brings the "fundamental changes", it changes the banks' working aspect, makes it easy to raise the capital, it changes the shape of money itself.

Fintech is a new catchword, which increases the potential for usage and reach of financial services significantly. Loo [34] stated that fintech can contribute greatly to consumers' wellbeing and it can also help to reduce the possibility of a financial disaster. The emergence of fintech is changing the operations of financial services extremely, by digitally it increases the working efficiency, easy approach to the customer, transparency in the financial services sector [35]. According to Gomber, Kauffman, Parker, \& Weber [35], the fintech innovations leave a core impact on service delivery, business infrastructure, which creates competition among key stakeholders of the market by restructuring the flow of financial services.

The financial industry pertains great importance in the daily life of the people of society, although the financial sector has gone through major transformations due to the emergence of fintech [36, 37]. Fintech is a new approach that brings challenges to the banking sector. Fintech is an unexplored phenomenon and pertains to the importance for academia, policymakers, and regulators of the financial service sector $[11,38,39]$.

Fintech appears as a vital phenomenon that required clear attention by the regulators of the financial industry for innovative technology, and adoption of that particular technology. Fintech is defined by the organization: "an acronym which stands for financial technology, combining bank expertise with modern management science techniques and the computer". In the present context, fintech can be described as the connection of modern technology, cloud computing, mobile internet, transfers of money, and different banking services [35].

Karandaaz Pakistan and FinSurgents [40] conducted the survey and reported that fintech revolution in Pakistan is at its pioneering stage. Noreen, Ghazali, and Mia [41] also highlighted that perceived trust and perceived risk are important factors towards the adoption of mobile money services. Global village Space [42] stated that covid-19 pandemic brings rapid changes towards digitalization of economy for financial inclusion. Fintech particularly mobile money services revolution offered significant opportunities for many unbanked people to participate to rise the financial inclusion level. Moreover, Pakistan is struggling to achieve the desired level of financial inclusion (50\%) via means of digital financial services [43]. The current rate of financial inclusion level via usage of mobile money services is presented in Table 1.

Table 1. Rates of Financial Inclusion in Pakistan

\begin{tabular}{|c|c|}
\hline Year & Rate of Financial Inclusion \\
\hline 2011 & $10 \%$ \\
\hline 2014 & $16 \%$ \\
\hline 2017 & $21 \%$ \\
\hline 2020 & $23 \%$ \\
\hline
\end{tabular}

Source: Demirguc-Kunt, Klapper, Singer, Ansar, and Hess (2018) and (Global Village Space, 2021)

Raza et al. [2] disseminated the review of financial inclusion in Pakistan. Zulfiqar, Chaudhary, and Aslam [44] also described financial inclusion factors, barriers, and effects for economic growth in Pakistan. Prior research in terms of agent banking, branchless banking, G2P payments, and mobile banking are available for digital inclusive financial growth in Pakistan $[45,46]$. Despite the increasing interest in financial inclusion by means of fintech, there is also a lack of works in the academic literature that deals with the steps taken by the SBP to enhance financial inclusion by the means of fintech. Therefore, this study provides insight on action taken by the SBP for the emergence of fintech to enhance financial inclusion.

\section{Materials and Methods}

In this study, literature focus on fintech practices to enhance financial inclusion in Pakistan commended by the SBP, Pakistan. Literature has been identified from Global Findex database, State bank of Pakistan, Global Competitiveness reports, reports by Karandaz, Financial inclusion program, research surveys, and research reports by different organizations. Electronic database searches had mainly been carried out using key terms in fintech, financial technology, fintech practices, financial inclusion, inclusive Pakistan, State Bank of Pakistan strategy for Financial Inclusion in Pakistan, National financial inclusion strategy. In this study, literature references have been cited for those studies that are available in full text. The website of the State Bank of Pakistan was also searched to find the related documents and reports of fintech and financial inclusion. Only those documents were written in English were considered for this review 
process. This study demonstrated only literature that included discussions, findings, and evidence related fintech and financial inclusion. Findings and discussion of this review study were based on currently available information, data, and evidence from published literature and documents that focus on fintech, financial technology, fintech practices, financial inclusion, inclusive Pakistan, by State banks of Pakistan.

\section{Findings and Discussion}

The following subsection focuses on the current status of fintech adoption and financial inclusion in Pakistan. The discussion also leads to review the current policies, programs, and strategies implemented by the Government of Pakistan to enhance the rate of financial inclusion in the country.

\subsection{Current Status of Financial Inclusion in Pakistan}

Pakistan has a very poor degree of financial inclusion, where the population has lack of access to formal or informal financial services. It was reported in Global findex 2017 that Pakistan is the third-largest country with a 100M unbanked population [9]. Furthermore, Global findex index survey shows the rate of financial inclusion in Pakistan after every three years as mentioned in Figure 3 below. The current rate of financial inclusion in Pakistan is $21 \%$ which is very poor as compared to other economies. Thus, according to the survey's reading, the rate of financial inclusion in Pakistan is shown in figure 3.

\subsection{Policies, Programs and Strategies related to Financial Inclusion in Pakistan}

This subsection focuses on the various policies, program, and strategies taken by the Government of Pakistan to enhance the rate of financial inclusion in Pakistan.

\subsubsection{State Bank of Pakistan's (SBP) Financial Inclusion Program (FIP)}

Figure 4 shows the diagrammatic representation of various FIP and strategies taken by the Government of Pakistan during the last decade. SBP implemented the FIP with the assistance of the "UK Department for International Development (DFID)". FIP goals at transforming the financial system to deliver equal access to financial services. FIP makes access possible for financially excluded specifically women and young people. FIP also emphasizes on providing access to financial services to the underprivileged segment of society.

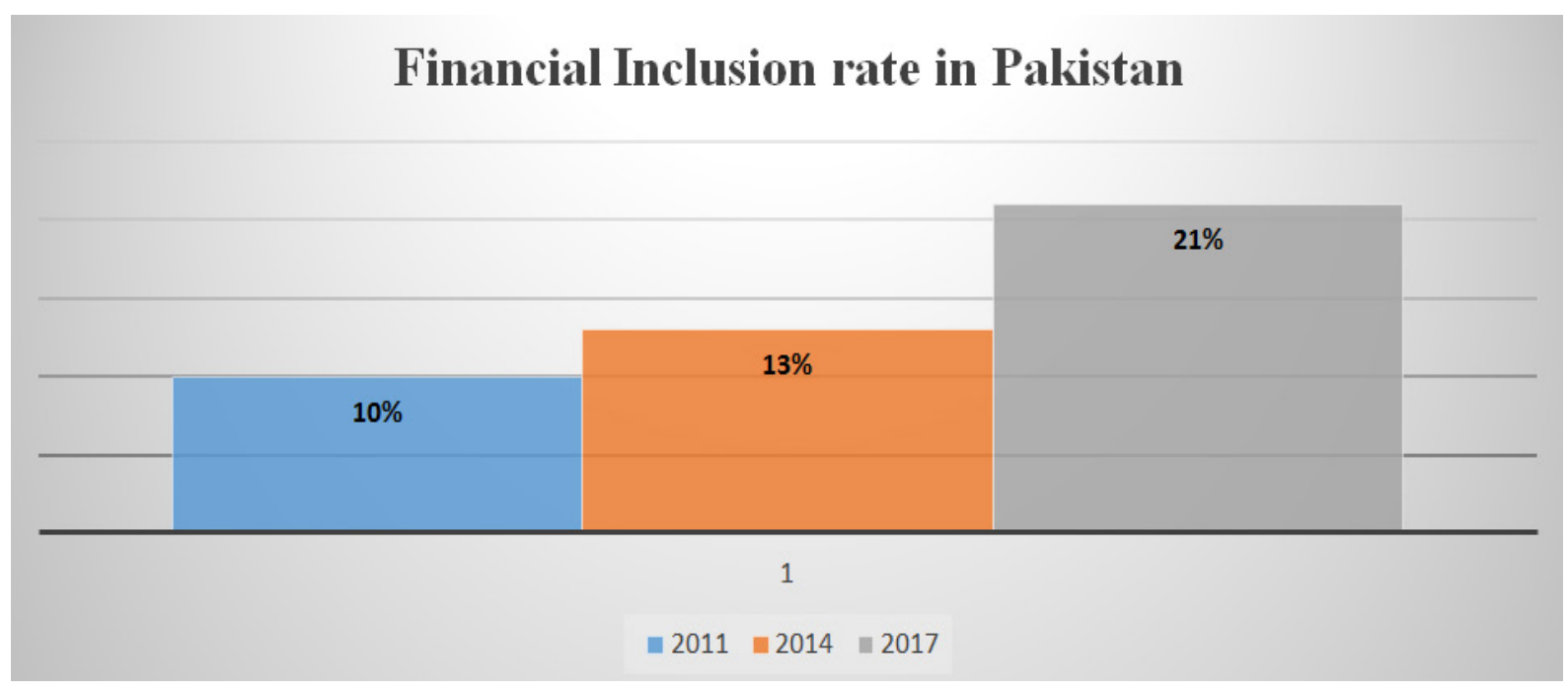

Source: Global findex index 2017

Figure 3. Financial Inclusion rate in Pakistan (2011-2017) 


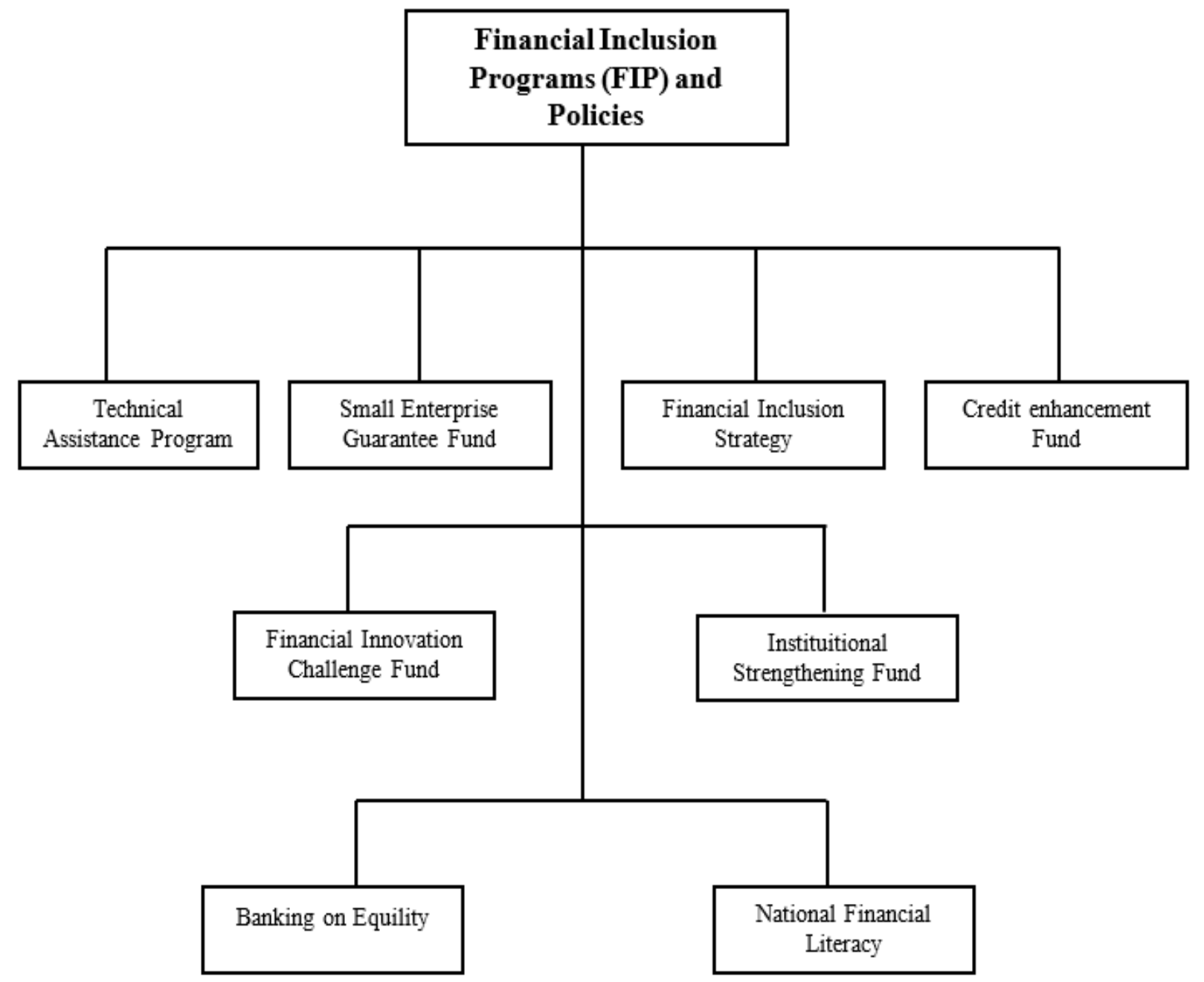

Source: State Bank of Pakistan 2020

Figure 4. FIPs Programs and Policies Structure

FIPs has also taken several measures for the development of the financial sector through product development, developing IT infrastructure, enhancing governance structure, and creating better systems \& control, etc. FIPs also focuses on loan requirements of the Micro \& Housing sectors, fosters innovations in rural and agriculture finance, digitizing of G2P payments, Islamic finance, and gender finance are the main focus. The program's success lies in its management framework and the creation of a strategic collaboration between private and public sectors [47]. Various FIPs programs and strategies are discussed briefly below.

\section{1-Credit Guarantee Scheme for Small and Rural Enterprises}

Credit Guarantee Schemes programs were introduced to motivate lenders for lending to the borrower by making some fractional payment to the lender. These programs were introduced to facilitate those, who do not have normally access to credit. For an emerging economy, the growth of Small and Rural enterprises is imperative. In rural areas, access to formal finance is a major problem that causes hinder the growth of small and micro-enterprises. Small and Rural Enterprises in Pakistan facing these obstacles for credit access from the capital market, Credit Guarantee Scheme would help to solve the issue of credit rationing [48].

\section{2-Microfinance credit guarantee facility guidelines (MCGF)}

The MCGF Facility is designed to allow Banks/DFIs to be a leader in reducing credit restrictions for MFBs/MFIs in their efforts to increase their outreach through the provision of loan facilities. It is anticipated that the Guarantees will help to establish the relationship between Banks/DFIs and micro borrowers. The Banks/DFIs familiarization with the customers should ultimately contribute to the borrower's graduation. The Banks/DFIs will assess MFBs/MFIs for the potential recipient based on the well-established requirement of due diligence. In this 
way, the Banks/DFIs can establish their sense of risk involved in microfinance through the credit enhancement facility. The guarantees will promote regulatory resolution that limits unsecured Banks/DFIs lending and will enforce banking regulations on MFBs/MFIs lending [49].

\section{3-Technical Assistance Fund (TAF)}

TAF was developed to ensure that SBP is central to developing, implementing, and managing the strategies and policies of financial inclusion. TAF also developed a regional policy to promote regional learning and cooperation to financial inclusion. It also established a Credit Information Bureau to get the data of the low-income market. It further developed a business ranking mechanism to solve the problem of loans to small businesses. The basic purpose was to strengthen the microfinance network. It developed channels to share knowledge with stakeholders through media. In addition, TAF conducts extensive analysis on regular basis to find out effective ways to spread financial information among the poor people as per the direction of the FinMark Trust [50].

\section{4- Financial Innovation Challenge Fund (FICF) Phase I, II, III}

A noteworthy innovation approach was applied as a catalyst in order to extend the scope of financial services in Pakistan. Accordingly, FICF promotes innovative technologies to develop digital financial markets, provide low-cost services, to ensure efficient implementation of system and process to provide new ways of satisfying customer demand for financial services. The FICF will focus on the challenge that the market will take to change the scope of financial services. Thus, FICF will be available to financial institutions, non-financial institutions, NGOs, telecommunication firms, and academic institutions.

FICF takes incentives for technological innovation and its practices that help the unbanked or the financially excluded community to get easy access to financial services. The broader objective of this fund is to provide access to financial services by innovative technology. Innovations may depend on advancements of technology such as smartphones or non-technological advancement, for example, value chain financing; serve as collateral for farmers for the loan guarantee or bridging of the market infrastructure gaps necessary to handle need-based financial services. FICF announced this challenge in three phases.

The 1st challenge phase focused on supporting "Financially Inclusive Government to Person (G2P) Payments via branchless banking models". In the first phase, FICF is to focus on the adoption of innovative approaches for G2P Payments e.g. pensions, salaries, and welfare payments for financially inclusive.

The 2nd challenge phase focuses on promoting innovation in rural and agricultural financial services. The Fund is supporting for agricultural and rural finance market through this round by using modern products and channels for the financially excluded population.

Currently, the 3rd phase of the challenge is promoting "Islamic Financial services to satisfy the latent demand for Shariah-compliant financial services in Pakistan".

\section{5-National Financial Inclusion Strategy (NFIS)}

SBP has established a National Financial Inclusion Strategy (NFIS) in conjunction with stakeholders to deals with the issue of the poor rate of financial inclusion in Pakistan. The Government of Pakistan has formally launched and adopted the strategy in May 2015. The aim of this strategy is to work with the different organizations for universal financial inclusion in the country. The NFIS set the vision, constructed the framework for fintech, makes the action plan, and sets the desired outcomes by using the means of fintech for financial inclusion. SBP makes this 100 days' agenda to enhance the financial inclusion up to $50 \%$ by 2020 [13].

\section{6-Financial Literacy \& Capacity Building Program}

There is an over 180 million population in Pakistan. However, diffusion is extremely low in the financial service sector, a very small chunk $(2.4 \%)$ of the people have access to loans from official financial organizations. A major chunk of the population is financially excluded by official financial institutions. One of the reasons for their financial exclusion is the lack of wakefulness of financial services and their usage. A large number of the population also have lack of skills in money management and financial management. Investing, saving, and budgeting are novel concepts for the people of Pakistan (State Bank of Pakistan). Under this literacy building program Government of Pakistan has implemented two different programs namely: National Financial Literacy Program and National Financial Literacy Program for Youth (NFLP-Y). Further details of these programs are as follows:

\section{National Financial Literacy Program}

In order to promote financial inclusion in Pakistan, SBP launched the program; "Nationwide Financial Literacy Program (NFLP) on 20th January 2012" by spreading financial education to boost and stable the economic growth in the country. The objective of this program is to target the youth and middle-income groups with the collaboration of different educational institutes phase-wise. The objective of this program is to provide an understanding of financial resource management.

\section{National Financial Literacy Program for Youth (NFLP-Y)}

"National Institute of Banking \& Finance" is collaborating with SBP for implementation of the 
"National Financial Literacy Program for Youth (NFLP-Y)" to provide knowledge about financial services in order to develop their understanding of financial management and improve their access to financial matters. The program is targeting the youth and school-going children across 45 selected districts of Pakistan including GB \& AJK. NFLP-Y aims at reaching out to 1.6 million children and youth through classroom training including digital learning up to 2023 [51].

\section{7-Banking on Equality}

Recently the Government of Pakistan launched the banking on equality program to enhance gender equality in financial inclusion. The SBP has developed a policy to encourage women to participate in financial inclusion in Pakistan, entitled "Banking on Equality: Reducing the Gender Gap in Financial Inclusion". A number of relevant organizations provide initial feedback on the level of financial inclusion surge among men while it remains stagnant among women. However, a high-profile webinar on 21 December 2020 began the process of consultation among stakeholders on the Banking Equality Policy (BoE) [52].

Governor of SBP, Dr. Reza Baqir conducted group discussions with senior-level participation from the federal government, corporate sector, civil society, women champions, and academia, etc. There was a discussion on a range of issues including, regulations and compliances, access to material including business identification and evidence, availability of collateral, awareness and promotion requirements, and need for collaboration among various stakeholders including civil society organizations. Similarly, Deputy Governor Ms. Sima Kamil separately conducted group discussions with the representatives of supply/demand side stakeholders to attain their feedback and to get know-how about the implementation of their policy. Participants on the supply side included CEOs, the President of the bank, Microfinance Banks and Institutions, DFIs, and NPOs, while on the demand side stakeholder from federal and sub-national chambers of commerce and industry groups, and women entrepreneurs, etc.

\subsection{Partnership \& Alliances for Enhancing Financial Inclusion}

In order to increase the financial inclusion level in the country, SBP enters into strategic alliances to support business growth and encouraging innovation. In other words, the Government of Pakistan has made various partnerships and alliances with a number of stakeholders for the successful implementation of the FIP program and strategies. SBP also has joined hands with "international financial institutions and development agencies" to attain the technical expertise, innovation knowledge, for market development, and to foster innovation (State Bank of Pakistan). The detail about key partners is as follows:

\section{i. Donors}

- $\quad$ UK Department for International Development

- $\quad$ The World Bank Group.

- Asian Development Bank UK Department for International Development

\section{ii. Strategic partners}

- Securities and Exchange Commission of Pakistan

- Pakistan Telecommunication Authority

- National Database and Registration Authority

- Controller General of Accounts

- Accountant General Pakistan Revenues

- Military Accountant General

- Pakistan Banks' Association

- Pakistan Microfinance Network

\section{iii. Implementing partners}

- Commercial/Islamic/Microfinance Banks.

- Microfinance Institutions.

- Telecommunication Companies

\section{Conclusions}

The present study shed light on various policies and strategies implemented by the Government of Pakistan to enhance the rate of fintech adoption and financial inclusion in the country. The study revealed that SBP has initiated various programs and policies such as MCGF, Credit Guarantee Scheme for Small and Rural Enterprises and TAP to provide loan facilities for rural development, agriculture finance, housing scheme, and under-served community to participate in financial system of the country. Furthermore, SBP invested in the fintech sector for launching the innovative technologies to get easy access to financial services and products. In addition, SBP launched the "National Financial Literacy Program for Youth (NPLP-Y)" to provide the necessary education about money management skills and improve their access to financial services. Very recently, SBP introduced a policy "Banking on Equality-Gender Financial inclusion" to encourage women to participate in financial system. Previous studies also reported that fintech has a greater potential to provide access of underprivileged segments of the society in the country to financial and non-financial institutions. There is a crucial need for a well-established fintech ecosystem in the country in order to exploit the potential benefits of fintech. This study provides an insight into financial inclusion policies and strategies taken by Pakistani Government which might be useful for the practitioners to enhance the rate of financial inclusion in the country.

\section{Acknowledgments}

This research received no specific grant from any 
funding agency in the public, commercial, or not-for-profit sectors.

\section{REFERENCES}

[1] Demirguc-Kunt, A., Klapper, L., \& Singer, D., "Financial inclusion and inclusive growth: A review of recent empirical evidence," The World Bank Policy Research Working Paper (8040), 2017.

[2] Raza, M. S., Fayyaz, M., \& Syed, N., "Overview of Financial Inclusion in Pakistan," International Journal of Management Sciences, vol. 6, no. 12, pp. 572-581, 2015.

[3] Prasad, M., "Financial Inclusion: Emerging Role of FinTech," FinTechs and an Evolving Ecosystem 85, vol. 1, no. 5,2019 .

[4] Demirguc-Kunt, A., Klapper, L., Singer, D., \& Van Oudheusden, P., "The global findex database 2014: Measuring financial inclusion around the world," Washington, DC: The World Bank Policy Research Working Paper (7255), 2015.

[5] Munyegera, G. K., \& Matsumoto, T., "Mobile money, remittances, and household welfare: panel evidence from rural Uganda," World Development, vol. 79, pp. 127-137, 2016.DOI:https://doi.org/10.1016/j.worlddev.2015.11.006.

[6] Demirguc-Kunt, A., \& Klapper, L., "Measuring financial inclusion: The global findex database," Washington, DC: The World Bank Policy Research Working Paper (6025), 2012.

[7] Levine, R., "Financial development and economic growth: views and agenda," Journal of economic literature, vol. 35, no. 2, pp. 688-726, 1997.

[8] Levine, R., "Finance and growth: theory and evidence," Handbook of economic growth, vol. 1, pp. 865-934, 2005.

[9] Demirguc-Kunt, A., Klapper, L., Singer, D., Ansar, S., \& Hess, J., "The Global Findex Database 2017: Measuring financial inclusion and the fintech revolution," Washington, DC: The World Bank publication, 2018.

[10] Makina, D., "The potential of Fintech in enabling Financial Inclusion: In Extending Financial Inclusion in Africa," London Wall, United Kingdom: Candice Janco, pp. 299-318, Academic press 2019.

[11] Dapp, T., Slomka, L., AG, D. B., \& Hoffmann, R., "Fintech-The digital (r) evolution in the financial sector," Deutsche Bank Research, vol. 11, pp. 1-39, 2014 b.

[12] Berg, T., Burg, V., Gombović, A., \& Puri, M., "On the rise of fintechs: Credit scoring using digital footprints," The Review of Financial Studies, vol. 33, no. 7, pp. 2845-2897, 2020.

[13] State Bank of Pakistan., "National Financial Inclusion Strategy Pakistan: State Bank of Pakistan Karachi," 2015b, Available at: https://www.sbp.org.pk/Finc/Strategy.asp (Accessed Mar. 1, 2021).

[14] Manyika, J., Lund, S., Singer, M., White, O., \& Berry, C., "Digital finance for all: Powering inclusive growth in emerging economies," McKinsey Global Institute, pp. 1-15,
2016.

[15] Dapp, T., Slomka, L., AG, D. B., \& Hoffmann, R., "Fintech-The digital (r) evolution in the financial sector," Deutsche Bank Research, Frankfurt am Main, vol. 15, no. 3, pp. 12-14, 2014b.

[16] Gosavi, A., "Can mobile money help firms mitigate the problem of access to finance in Eastern sub-Saharan Africa?," Journal of African Business, vol. 19, no. 3, pp. 343-360, 2018.

[17] Govt. of Pakistan., "Education Population by Level of Education," Pakistan Bureau of Statistics, 2019 (Accessed Mar. 1, 2021).

[18] Kpodar, K., \& Andrianaivo, M., "ICT, financial inclusion, and growth: Evidence from African countries," International Monetary Fund Working Paper 2011, no. 073.

[19] World Bank., "UFA2020 Overview: Universal Financial Access by 2020," 2016. (Accessible at: http://www.worldb ank.org/en/topic/financialinclusion/brief/achievinguniversa 1-financial-access-by-2020) (Accessed Jan. 5, 2021).

[20] DFID., "Designing and Implementing Financially Inclusive Payment Arrangements for Social Transfer Programmes," Department for International Development. A Policy Manual. London: DFID, 2009.

[21] Aduda, J., \& Kalunda, E., "Financial inclusion and financial sector stability with reference to Kenya: A review of literature". Journal of Applied Finance and Banking, vol. 2, no. 6, pp. 95-120, 2012.

[22] Morawczynski, O., Hutchful, D., Cutrell, E., \& Rangaswamy, N., "The bank account is not enough: Examining strategies for financial inclusion in India," Paper presented at the Proceedings of the 4th ACM/IEEE international conference on information and communication technologies and development, 2010.

[23] Goland, T., Bays, J., \& Chaia, J., "From millions to billions: Achieving full financial inclusion," McKinsey \& Company, 2010.

[24] Sahrawat, R. "Financial inclusion from obligation to opportunity," Tata Consultancy Service Ltd, 2010.

[25] World Bank., "Financial inclusion on the rise, but gaps remain [WWW Document]" 2018. (Press Release. https://www.worldbank.org/en/news/pressrelease/2018/04/ 19/financial-inclusion-on-the-rise-but-gaps-remain-globalfindexdatabase-shows) (Accessed Dec. 20, 2020).

[26] Aker, J. C., \& Mbiti, I. M., "Mobile phones and economic development in Africa," Journal of economic Perspectives, vol. 24, no. 3 , pp. 207-232, 2010

[27] Wesolowski, A., Eagle, N., Noor, A. M., Snow, R. W., \& Buckee, C. O., "Heterogeneous mobile phone ownership and usage patterns in Kenya," PloS one, vol. 7, no. 4, pp. e35319, 2012.

[28] Zavolokina, L., Dolata, M., \& Schwabe, G., "FinTech transformation: How IT-enabled innovations shape the financial sector. Paper presented at the FinanceCom 2016, 2016.

[29] Gai, K., Qiu, M., \& Sun, X., "A survey on FinTech. Journal of Network and Computer Applications," vol. 103, no. 1, pp. 
262-273, 2018.

[30] Chanson, M., Risius, M., \& Wortmann, F., "Initial coin offerings (ICOs): An introduction to the novel funding mechanism based on blockchain technology: Emergent research forum (ERF)." In proceedings of the $24^{\text {th }}$ Americas Conference on Information Systems (AMCIS) 2018.

[31] Chuen, L. D. K., \& Teo, E. G., "Emergence of FinTech and the LASIC Principles," Journal of Financial Perspectives, vol. 3 no. 3, pp. 1-17, 2015.

[32] Lee, I., \& Shin, Y. J., "Fintech: Ecosystem, business models, investment decisions, and challenges," Business Horizons, vol. 61, no. 1, pp. 35-46, 2018.

[33] Wójcik, D., "Geographies of Finance I: Exploring FinTechmaps and concepts," Progress in Human Geography, 2020.

[34] Loo, R. V., "Making innovation more competitive: the case of Fintech," UCLA L. Rev. 65, pp. 232, 2018.

[35] Gomber, P., Kauffman, R. J., Parker, C., \& Weber, B. W., "On the fintech revolution: Interpreting the forces of innovation, disruption, and transformation in financial services," Journal of Management Information Systems, vol. 35, no. 1, pp. 220-265, 2018.

[36] Berger, A. N., "The economic effects of technological progress: Evidence from the banking industry," Journal of Money, credit and Banking, vol. 35, no. 2, pp. 141-176, 2003.

[37] Shim, Y., \& Shin, D.-H., "Analyzing China's fintech industry from the perspective of actor-network theory," Telecommunications Policy, vol. 40, no. (2-3), pp. 168-181, 2016.

[38] DeYoung, R., "The performance of Internet - based business models: Evidence from the banking industry," The Journal of Business, vol. 78, no. 3, pp. 893-948, 2005.

[39] Schueffel, P., "Taming the beast: A scientific definition of fintech," Journal of Innovation Management, vol. 4, no. 4, pp. 32-54, 2016.

[40] Karandaaz Pakistan, \& FinSurgents. (2017). Seeding Innovation-A Framework for Rooting Fintechs in Pakistan.

[41] Noreen, M., Ghazali, Z., \& Mia, M. S. (2021). The Impact of Perceived Risk and Trust on Adoption of Mobile Money
Services: An Empirical Study in Pakistan. The Journal of Asian Finance, Economics and Business, 8(6), 347-355.

[42] Global Village Space. (2021). Fintech revolution at Pakistan's doorstep - do you know what it is? Global Village Space.

[43] Fischer, G., Blumenstock, J., \& Khan, A. (2018). Driving usage of mobile money in Pakistan. Available at: https://www.theigc.org/project/driving-usage-of-mobile-m oney-in-pakistan/.

[44] Zulfiqar, K., Chaudhary, M. A., \& Aslam, A., "Financial inclusion and its implications for inclusive growth in Pakistan," Pakistan Economic and Social Review, vol. 54, no. 2, pp. 297-325, 2016.

[45] Kemal, A. A., "Mobile banking for financial inclusion in Pakistan," PhD diss., Anglia Ruskin University, 2016.

[46] Zahid, M., Rahman, H. U., Makki, B. I., Jehang, M., \& Rehman, S., "Branchless Banking in Pakistan: Opportunities and Challenges," NFC IEFR Journal of Engineering and Scientific Research, vol. 5, 2017. DOI:10.24081/nijeser.2017.1.0014.

[47] State Bank of Pakistan., "Financial Inclusion Program Components," 2019. Available at: https://www.sbp.org.pk/ Finc/About.asp (Accessed Feb. 10, 2021).

[48] State Bank of Pakistan., "Credit Guarantee scheme for Small and Rural Enterprises." 2011. Available at: https://www.sbp.org.pk/smefd/circulars/2011/C2-Annex/S cheme.pdf (Accessed Feb. 10, 2021).

[49] State Bank of Pakistan., "Microfinance credit guarantee facility guidelines," 2015a, Available at:https://www.sbp.o rg.pk/acd/2015/C1-Annex-MCGF-Guidelines.pdf (Accessed Feb. 10, 2021).

[50] State Bank of Pakistan. "SBP Financial Inclusion Programs (FIP)" 2015c, available at: https://www.sbp.org.pk/Finc/A bout.asp (Accessed Feb. 10, 2021).

[51] State Bank of Pakistan., "National Financial Literacy Program for Youth (NFLP-Y)," 2018. Available at: https://www.sbp.org.pk/Finc/FL.asp (Accessed Feb. 10, 2021).

[52] State Bank of Pakistan., "Banking on Equality-Gender Financial inclusion policy," 2021. Available at: https://www.sbp.org.pk/events/2021/BankingonEquality/in dex.asp (Accessed May. 07, 2021). 